DOI 10.4467/25439561KSR.21.009.14420

DARIA SEREBRENNIK (D) https://orcid.org/0000-0003-4099-6351

Uniwersytet Humanistyczno-Przyrodniczy im. Jana Długosza

w Częstochowie

\title{
ДЕТСКАЯ КНИГА И БОРЬБА ЗА ФОРМИРОВАНИЕ ИДЕАЛА СОВЕТСКОГО ЧЕЛОВЕКА (1918-1930)
}

\author{
CHILDREN'S BOOKS AND THE STRUGGLE FOR THE FORMATION \\ OF THE IDEAL OF THE SOVIET MAN (1918-1930)
}

Резюме

В статье рассматриваются пути влияния руководящей Партии СССР на воспитание ребенка через один из видов массовой культуры - детскую литературу. Начало ХХ века, а именно первые два десятилетия послереволюционного периода, знаменательно пристальным вниманием к детству, что обусловлено социально-политической парадигмой новой страны и необходимостью влиять на ребенка с целью воспитания нового типа советского гражданина, «человека будущего», который построит идеальное коммунистическое государство. Детская литература в только что созданной стране стала не просто адресована ребенку, а максимально обозначена с точки зрения социальных функций: ее описали и разбили на возрастные категории, указали темы и жанры, поставили задачи воспитания и образования. В предвоенные годы созываются различные тематические конференции, съезды и совещания; создаются многочисленные инстанции и издательства, призванные объединить силы лучших писателей, художников, педагогов и ликвидировать существующие недостатки в работе по созданию и продвижению детских книг, выдержанных высоким идейным уровнем. Отныне детская книга становится самостоятельным художественным явлением и рассматривается как мощный инструмент в идеологической борьбе за становление нового человека, а детство - как важнейший период, способствующий воспитанию человека, отвечающего высшим идеалам. 


\begin{abstract}
The article examines the ways in which the leading party of the USSR used to influence children's upbringing by means of one of the types of mass culture - children's literature. The beginning of the 20th century, namely, the first two decades of the post-revolutionary period, were remarkable as for close attention to childhood, which resulted from the socio-political paradigm of the new country and the need to influence the child in order to educate a new type of Soviet citizen, a "man of the future" who would build an ideal communist state. Children's literature in the newly created country was not addressed just to the child, but it was divided into categories regarding its social functions - taking into account the reader's age. Topics and genres were pinpointed, the tasks aiming at proper upbringing and education were set. In the pre-war years various thematic conferences, congresses and meetings were convened; and numerous institutions and publishing houses were created to unite the power of the best writers, artists, teachers and to eliminate existing shortcomings in the work on creation and promotion of children's books with high ideological level. From now on, children's books have become an independent artistic phenomenon. They are viewed as powerful tool in the ideological struggle for the formation of a new Soviet man, whereas childhood is perceived as the most important period in shaping personality of the man of high ideals.
\end{abstract}

Ключевые слова: детство, новый человек, советская детская литература, советский писатель, советская идеология

Keywords: childhood, new Soviet man, Soviet children's literature, Soviet writer, Soviet ideology

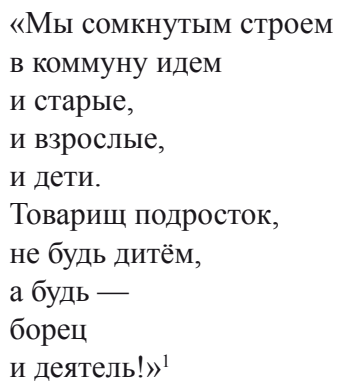

В.В.Маяковский, Товарищу подростку (1930)

Общемировые истоки детской литературы, как и вся мировая литература, лежат в архаических цивилизациях, в фольклоре, в истории становления различных религий. На развитие детской литературы оказали влияние про-

${ }^{1}$ В. Маяковский, Большое собрание стихотворений и поэм в одном томе, Москва, Эксмо, c. 947 . 
изведения устного народного творчества, передаваемые из поколения в поколение ${ }^{2}$. Становлению детской литературы в России способствовали различные историко-культурные процессы развития страны: от возникновения письменности, распространения грамотности на Руси и развития книгопечатания до взаимодействия с культурными традициями других стран. У каждого века были свои черты и особенности, сильное влияние имели также педагогические идеи того или иного времени и собственно отношение к детям.

Начало ХХ века, а точнее его послереволюционный период, ознаменовалось пристальным вниманием к ребенку и детству. Литературным произведениям для детей придают особую значимость: их разбивают на возрастные категории, определяют их адресата, формулируют задачу и темы, наполненные политикоидеологическим контекстом в связи с социалистической концепцией построения нового государства и необходимостью влиять на ребенка с целью воспитания нового типа советского гражданина. Отныне детская книга становится одним из значимых инструментов в идеологической борьбе за становление нового человека. Литературе в общем, и детской в частности, в Советском союзе придают все черты научности. В самом этом понятии начинают формировать комплекс художественных и научно-художественных произведений, адресованный непосредственно детям с учетом их психофизиологического развития и восприятия, а также осуществляющий задачи воспитания и образования подрастающего поколения ${ }^{3}$.

В 1918 году Леонард Юлианович Пирагис ${ }^{4}$, писатель и редактор детских журналов, говоря о значении детской литературы в формировании и укреплении государственного могущества, называет детскую книгу гипнозом, поскольку ребенок не просто читает книгу, а «впивается в нее нежными ростками души». Идеи, «правильным образом» заложенные в книгу, создавали «благоприятную почву для будущих убеждений» в душе юных читателей. При становлении нового строя - «райской обители социализма» - Пирагис упорно напоминает о роли детской книги «как важном оружии воспитания», «слишком сильном оружии», которое нужно очистить от яда и мусора предыдущих лет, преобразовать, усовершенствовать и довести до юных читателей. С тех пор слово

2 А. Кузнецов, Детская литература, «Универсальная научно-популярная онлайнэнциклопедия "Кругосвет“"», [в:] https://www.krugosvet.ru/enc/kultura_i_obrazovanie/literatura/ DETSKAYA_LITERATURA.html [дата обращения: 07.04.2020].

3 Ю. Соколов, Детская литература, [в:] Литературная энииклопедия: Словарь литературных терминов: в 2-х m., ред. Н. Бродского, А. Лаврецкого, Э. Лунина, В. Львова-Рогачевского, М. Розанова, В. Чешихина-Ветринского, Москва, Ленинград, Издательство Л.Д. Френкель, 1925, сс. 194-195.

${ }^{4}$ Более известен под псевдонимом Л. Кормчий, где инициал «Л» не расшифровывается. 
«оружие» часто можно услышать применительно к детской литературе, что неудивительно, поскольку «дети - наше будущее. Потомство наше - фундамент, на котором должно строиться новое здание; оно - почва, которую нужно подготовить надлежащим образом» ${ }^{5}$.

С самого начала создания первого в мировой истории социалистического государства будущие идеологи и руководители страны определили одну из главных своих задач: построение нового общества. Владимир Ильич Ленин, главный идеолог и основатель страны, был убежден, что одними указами страна не изменится, нужно взращивать другого гражданина, «человека будущего», «строить коммунизм с тем запасом человеческих сил, что остался от прошлого [царского-Д.С.] общества, но при этом коренным образом меняя учение и воспитание молодежи» ${ }^{6}$. Новое общество требовало изменения массового человека в процессе социалистического на него влияния ${ }^{7}$, необходима была работа по смене идейного сознания человека. И если взрослого человека нужно было постепенно переключать на новую действительность, то детей предлагалось воспитывать уже на раннем этапе жизни с чистого листа ${ }^{8}$, ведь именно в начальный период жизни ребенка среда и общество являются решающими факторами для принятия норм и правил дальнейшего бытия человека ${ }^{9}$. Ребенка считали тем самым новым человеком, который заменит взрослых ${ }^{10}$ и построит идеальное коммунистическое государство.

В стране начали искать пути влияния на ребенка: рассматривались вопросы «правильного» воспитания подрастающего поколения в духе революционной идеологии, для чего включались все доступные средства массовой информации, в том числе кино, радио и другие виды искусства, которые провозглашали коммунистическую мораль, пропагандировали советский образ жизни и семейнообщественные ритуалы. «Массовая культура становится одним из основных инструментов формирования нового человека, а ее оружием является манипуляция» ${ }^{11}$. В такой обширной медиа-среде воспитание ребенка посредством чтения

5 Л. Кормчий, Забытое оружие. О детской книге, «Правда» 1918, № 28, 17 февраля, с. 3.

${ }^{6}$ В.И. Ленин, Задачи союзов молодежи. Речь на III Всероссийском съезде Российского Коммунистического Союза Молодежи 2 октября 1920 года, [в:] его же, Полное собрание сочинений в 55 томах, Москва, Издательство политической литературы, т. 41, с. 301.

${ }^{7}$ А.Б. Залкинд, Педология в СССР, Москва, Работник просвещения, 1929, с. 6.

${ }^{8}$ А.В. Блюм, Советская ичензура в эпоху тотального террора 1929-1953, Санкт-Петербург, Академический проект, 2000, с. 211.

${ }^{9}$ А.Б. Залкинд, Педология в СССР ..., указ. соч., с. 6.

10 Л. Кормчий, Забытое оружие..., указ. соч., с. 3.

${ }^{11}$ L. Suchanek, Kultura masowa $w$ Rosji i radziecki eksperyment antropologiczny, «Kultura Słowian. Rocznik Komisji Kultury Słowian PAU» 2016, т. XII, с. 7. Здесь и далее перевод цитат с иностранных языков на русский выполнен автором настоящей статьи, если не указано иначе. 
являлось только одним из звеньев. Однако руководство страны отводило важную роль литературе, которая поможет сформировать в человеке необходимые культурные ценности, нормы поведения в социуме, правила жизни и морали (например, на уровне дихотомий добрый-злой, дружба-вражда, хорошо-плохо). Недаром всем известное стихотворение Владимира Владимировича Маяковского Что такое хорошо и что такое плохо?, написанное им в 1925 году, Дмитрий Владимирович Фомин, российский искусствовед, сравнивает с кодексом или словарем по этикету для детей, по которому ребенку легче ориентироваться в мире взрослых ${ }^{12}$. Многими своими произведениями Маяковский призывает детей скорее вырасти, стать самодостаточными и наравне со взрослыми идти строем в светлое будущее ${ }^{13}$. Таким образом, детская литература СССР подверглась масштабным изменениям, а дети «в СССР в беспрецедентном масштабе стали предметом политической игры, которая должна была укрепить позиции Иосифа Виссарионовича Сталина и в то же время преобразовать общество путем реализации принципов коллективной этики» ${ }^{14}$.

Если Маяковский призывает в своем творчестве молодое поколение скорее повзрослеть, то государственная верхушка стремится к инфантилизации всего общества. Глава партии, управляющей страной, народом, каждым человеком, был объявлен вождем, страна была разделена на «отцов» и «детей», где «отцы» - это партия, управляющая человеческой массой, а «дети» - невежественные люди, которым нужно открывать глаза. Начался путь трансформации взрослого в ребенка: руководство страны становилось старшими членами его семьи, а вождь - духовным Отцом, ради которого не только свою настоящую семью предать можно, но и жизнь отдать не жалко ${ }^{15}$.

Исследователи и историки приводят разные идеальные образы нового человека - героя нового времени: от «революционера-разрушителя старого мира» до «индустриального человека», «усовершенствованного коммунистического человека» ${ }^{16}$, от которого требовались идейность, энергия и инициатива. Существовало представление об идеальном человеке как о коллективисте, физически и интеллектуально развитом, ставящем общее выше частного, трудоспособном и организованном - своего рода машине, о чем нередко заявлял один из большевистских идеологов Николай Иванович Бухарин:

12 Д.В. Фомин, Вступление, [в:] В.В. Маяковский, Что такое хорошо и что такое плохо, репринтное издание, Москва, Арт-Волхонка, 2018, суперобложка.

${ }^{13}$ Там же.

${ }^{14}$ M. Brzóstowicz-Klajn, Pawlika Morozowa wzorzec, [в:] Słownik realizmu socjalistycznego, ред. Z. Łapiński, W. Tomasik, Kraków, Universitas, 2004, с. 184.

${ }^{15}$ М.Я. Геллер, Машина и винтики. История формирования советского человека, Лондон, Overseas Publications Interchange Ltd, 1985, c. 40.

${ }^{16}$ Там же, с. 10. 
«Перед нами проблема обработки людей [...] и превращение их в такие живые машины, которые бы во всех своих действиях [...] руководствовались бы новыми принципами, новой пролетарской идеологией» ${ }^{17}$.

К 1930-м годам в искусстве был провозглашен социалистический реализм, это привело к тому, что в литературу ввели образы и биографии реально существующих людей. Согласно идеологии равенства, образ нового человека должен был быть положительным, побуждающим к активным действиям на пользу страны, вдохновляющим на новые подвиги. В литературе появилось много «идеальных героев»: комсомольцы, пионеры, ударники труда, мудрые старцы, спортсмены. В детской литературе образ ребенка словно взрослеет: авторы изображают его в виде маленького героя с чертами взрослого человека. Из послереволюционных сирот, беспризорников и хулиганов в коллективе воспитывают образованного и честного человека, будущего «строителя коммунизма» (что хорошо показано в повести Григория Георгиевича Белых и Л. Пантелеева ${ }^{18}$ Республика ШКИД) ${ }^{19}$. Сталин, говоря об идеальном человеке нового общества, назвал его винтиком огромной машины под названием государство ${ }^{20}$.

Одним из реально существующих «борцов за советскую власть» того времени был мальчик Павлик Морозов, в современном мире имеющий репутацию то героя, то предателя. Юрий Ильич Дружников, русский писатель, журналист и историк литературы, в своем документальном расследовании жизни и убийства самого известного на всем советском и постсоветском пространстве пионера, ставшего героем и символом своей страны за донос на отца, показывает великие схемы манипуляции, производимые правительством, механизм работы государственной пропаганды 30-х годов. Из обычного, никому не известного мальчика Павлика Морозова, о существовании которого при его жизни не знали за пределами его далекой деревни, журналисты и писатели того времени сделали национального героя огромной страны только потому, что такой герой понадобился аппарату пропаганды для создания образца человека, «наделенного нужными качествами, эталона, по которому

${ }^{17}$ Н.И. Бухарин, Борьба за новых людей, [в:] его же, Борьба за кадры. Речи и статьи, Москва, Ленинград, Молодая гвардия, 1926, с. 25-26.

${ }^{18}$ Инициал Л в этом псевдониме не расшифровывается, настоящее имя: Алексей Иванович Еремеев.

19 Т.В. Демидова, Образ идеального советского человека в печати СССР 1930-х годов, «Исторические, философские, политические и юридические науки, культурология и искусствоведение. Вопросы теории и практики» 2012, № 4 (18): в 2-х ч, ч. I, сс. 50-52.

${ }^{20}$ М.Я. Геллер, Машина и винтики..., указ. соч., с. 10. 
можно [...] делить людей на своих и врагов» ${ }^{21}$. Этот миф создавался для «идеологической подготовки юношества к служению партии и воспитания преданности». Таким образом мальчик, который никогда не был пионером, и его семья, ставшая лишь жертвой режима того времени, оказались инструментами идеологической борьбы. Правительство, подтасовывая документы и подменяя факты, провело громкий, освещаемый в прессе, показательный процесс запугивания крестьян с целью внедрения колхозного строя и воспитания среди населения возмущения и ярости к кулачеству ${ }^{22}$. Создавая нужных ей героев, партия ждала от своих «детей» подчинения и предпочтение кровным узам духовного с ней - партией - родства.

Сверстники Павлика Морозова - поколение, родившееся уже в послереволюционные годы, - не имели за плечами старых моральных принципов, они были готовы преданно следовать указам вождя. Именно для них Павлик Морозов был провозглашен «ярким примером для всех детей Советского Союза» ${ }^{23}$. По указу сверху о Павлике слагали стихи, писали книги, ставили пьесы для детских театров. Образ Павлика успешно использовался для создания нового типа человека, которого приучали к жизни среди врагов, к борьбе за дело рабочего класса и строительству социализма.

Вопрос о Морозове рассматривался на Первом съезде советских писателей в 1934 году. Максим Горький, избранный почетным председателем съезда, отметил, что

«рост нового человека особенно ярко заметен на детях. [...] Впервые за всю жизнь человечества дети являются [...] наследниками действительной и могущественной ценности - социалистического государства, созданного трудом отцов и матерей» ${ }^{24}$.

Докладчик, называя детей сознательными и строгими судьями прошлого, ожидает от них суждения и даже осуждения своих родителей и пересказывает историю про девочку, которая наябедничала врачу на своего отца. Горький призывает детей следить и сообщать, что, по его мнению, позитивно скажется на более заботливом и нежном отношении отцов к своим детям ${ }^{25}$. Писатель

${ }^{21}$ Ю.И. Дружников, Доносчик 001, или Вознесение Павлика Морозова, Москва-Augsburg, Im Werden Verlag, 2003, c. 52.

${ }^{22}$ Там же, с. 52.

${ }^{23}$ Доклад заместителя председателя Центрального бюро юных пионеров Василия Архипова. Цит. по Ю.И. Дружников, Доносчик 001..., указ. соч., с. 52.

${ }_{24}$ Доклад А.М. Горького о советской литературе, [в:] Первый Всесоюзный съезд советских писателей 1934. Стенографический отчет, Москва, Государственное издательство Художественная литература, 1934, с. 15.

25 Там же. 
идеализировал Морозова, действительно считал его героем и пропагандировал молодежь следовать примеру Павлика, т. е., как пишет Геллер, предлагал пионерам охотиться на расхитителей социалистической собственности в первую очередь в своей семье ${ }^{26}$. И пионеры не подвели, объявив на первом съезде писателей, что таких павликов в стране уже тысячи ${ }^{27}$.

Горький верил, что Советский Союз, будучи государством молодым, отказывается от старого, имперского быта и создает новую культуру, цель которой - пробудить в человеке чувство собственного достоинства, сознания самого себя как силы, меняющей мир ${ }^{28}$. Новому человеку старались привить такие качества, как стремление к знаниям и труду, любовь к спорту и новому укладу, веру в то, что этот новый человек, являющийся частью рабоче-крестьянского общества, станет не только хозяином производства, но и непосредственно хозяином самой страны, а потому несет ответственность перед ней ${ }^{29}$.

«Он чувствует себя творцом нового мира. [...] Он - сила, которая только что осознала свой путь, своё значение в истории, и он делает своё дело культурного строительства со всей смелостью, присущей юной, ещё не работавшей силе, руководимой простым и ясным учением» ${ }^{30}$.

Горький призывает своих коллег по перу объединиться в «коллективное целое, как мощное орудие социалистической культуры», которое позволит им «понять свою коллективную силу» и целевые установки, при этом от Партийного руководства он ждет не только идеологических учений, но и морально авторитетной силы ${ }^{31}$.

Перед Политбюро стояла, однако, более масштабная цель - создать советского писателя, владеющего самоконтролем, превращая его в главного критика и цензора собственных произведений. Действовало при этом государство очень жестоко: для установления соцреализма как единого творческого метода и единственного стиля советского искусства государственной машиной в тридцатые годы было уничтожено огромное количество талантливых деятелей искусства, которые не реализовывали идеи партии.

${ }^{26}$ М.Я. Геллер, Машина и винтики..., указ. соч., с. 201.

${ }^{27}$ Согласно отчету в газете «Комсомольская правда» от 20.08.1934 пионерка Алла Каншина выступила после содоклада Самуила Маршака о детской литературе с поддержкой идеи М. Горького установить памятник П. Морозову, заявив «А ведь у нас таких тысячи!».

${ }_{28}^{28}$ Доклад А.М. Горького о советской литературе..., указ. соч., с. 14.

29 М. Горький, О старом и новом человеке, [в:] его же, Публииистические статьи, Ленинград, ОГИЗ, 1933, с. 360.

30 Там же, с. 361.

${ }^{31}$ Доклад А.М. Горького о советской литературе..., указ. соч., с. 17. 


\section{Геллер утверждает:}

«создание Нового мира требует создания Нового человека. Создание новой культуры - требует творца нового типа. [...] Задача заключалась в том, чтобы вырастить новый тип художника, который не только удовлетворился бы сознанием того, что Маркс-Энгельс-Ленин-Сталин нашли истину, раз и навсегда, но и согласился бы получать - как паек - порции истины, выделяемые Политбюро. Для выполнения этой задачи партия приняла решение стать соавтором советского художника, проникнуть в гены искусства» ${ }^{32}$.

С первых дней становления нового мироустройства одной из самых обсуждаемых тем на повестках заседаний руководителей страны оставались вопросы развития детской литературы и творчества для детей. Буквально за одно десятилетие было создано сразу несколько инстанций, занимающихся вопросами (в том числе - контролем и цензурой) не только школьного образования и ликвидации неграмотности, но также формирования института литературы, призванного выполнять функции по воспитанию нового человека, что привело к непрекращающимся на всех платформах дискуссиям о влиянии детской литературы на эти процессы.

Так, уже в ноябре 1917 года была образована Государственная комиссия по Народному Просвещению (ГКП), преобразованная через полгода в Народный Комиссариат Просвещения (Наркомпрос), руководителем которого был Анатолий Васильевич Луначарский. Орган контролировал деятельность культурнопросветительских организаций от образовательных до творческих объединений ${ }^{33}$.

В 1920 году почти одновременно были учреждены две организации. Одна из них - Институт по детскому чтению (ИДЧ), который, как гласит официальное положение, принятое на заседании Коллегии Наркомпроса, призван был заниматься

«теоретическим и практическим изучением детской литературы, методической разработкой детского чтения, изучением психологии читателя: ребенка, подростка и детской книги; собиранием материалов по вопросам детской литературы, детской психологии, детского творчества и детских библиотек, способствованием улучшению детской книги в педагогическом и художественном отношении» ${ }^{34}$.

${ }^{32}$ М.Я. Геллер, Машина и винтики..., указ. соч., с. 240.

33 Декрет Совета Народных Комиссаров. Об организации дела народного образования в Российской Республике (Положение.), [в:] Собрание узаконений и распоряжений рабочего и крестьянского правительства. Отдел первый, Москва, 1918, № 46, с. 551.

${ }^{34}$ Приложение к протоколу заседания № 68 (n. 9) Коллегии Народного комиссариата по просвещению РСФСР. Положение об Институте по детскому чтению, принятое на заседании Коллегии Наркомпроса РСФСР 15 июля 1920 г., [в:] Архив новейшей истории России. Протоколь и постановления Наркомпроса РСФСР. В 3 кн. Кн. 3. Январь - декабрь 1920 г., Москва, 2016, cc. 428-429. 
В задачи второй, названной Главным политико-просветительским комитетом, входила ликвидация неграмотности, организация библиотек, клубов, школ для взрослых. Председателем Главполитпросвета была общественная и культурная деятельница, организатор и главный идеолог советского образования и коммунистического воспитания молодёжи Надежда Константиновна Крупская.

В 1921 году «для проведения в жизнь реформы высших учебных заведений и учебных учреждений РСФСР ${ }^{35}$ был создан Государственный ученый совет (ГУС), который непосредственно осуществлял надзор над произведениями для детей, а также утверждал учебные планы, пособия для школ, преподавателей вузов и исследовал детскую литературу с научной точки зрения ${ }^{36}$. ГУС сыграл немалую роль в становлении детской литературы.

В 1922 году был создан ведущий контролирующий орган - Главное управление по делам литературы и издательств (Главлит) ${ }^{37}$, основной целью которого было «объединение всех видов цензуры печатных произведений» ${ }^{38}$ и защита государственных секретов в средствах массовой информации. Главлит просматривал все произведения, предназначенные к опубликованию, исправляя рукописи, разрешая или запрещая их к печати, строго следя за идеологической направленностью художественной литературы для детей, пропуская лишь произведения, способствующие коммунистическому воспитанию.

Надеждой Крупской была создана Комиссия по детской книге, разработавшая Основные требования к детской книжке, в которой указано, что огромная часть художественного наследия противоречит задачам воспитания, книга должна «содействовать развитию у детей общественных инстинктов, стремления к жизни в коллективе» ${ }^{39}$, при этом волшебные сказки признались вредным. ГУС поставил задачу собрать рекомендательный каталог детских книг, что по сути становилось цензурой и контролем детской литературы в рамках Основных требований. С января 1928 года Комиссия ГУСа начала выпускать бюллетень Книга детям, ставший основной площадкой для обсуждения проблемных материалов, в том числе здесь публиковались статьи и тезисы, отличающиеся идеологическим и воспитательным направлением, авторами которых

354 марта. Декрет СНК об учреждении Государственного ученого совета, [в:] Декреть Советской власти. T.IV. 10 ноября 1918 г. - 31 марта 1919 г., Москва, 1968, сс. 639-640.

${ }^{36}$ О.С. Октябрьская, Пути развития русской детской литературы ХХ века, Москва, МАКС Пресс, 2012, сc. 10-11.

${ }^{37}$ Декрет от 6 июня 1922 года. Положение о Главном управлении по делам литературь и издательств (Главлит), «Открытый текст. Электронное периодическое издание», http://opentextnn.ru/old/censorship/russia/sov/law/snk/1922/index.html@id=3382 [дата обращения: 10.01.2021].

${ }^{38}$ Там же, п. 1.

${ }^{39}$ Н. Тумова, На ниве просвещения, «Учительская газета» № 09 от 26 февраля 2019, https:// ug.ru/na-nive-prosveshheniya/ [дата обращения: 25.05.2021]. 
в основном были педагоги-партийцы, также велись обсуждения о негативном влиянии общения говорящих зверей с детьми через детские книги. Бюллетень выполнял скорее официальную инструкцию, нежели был действительной площадкой для дискуссий специалистов с ведомствами, и не имел конструктивной критики ${ }^{40}$.

Надежда Крупская была ярким представителем правительства, боровшимся за содержание детской литературы, ее воспитательный потенциал и реализм как «отражение действительности» ${ }^{41}$. Крупская стала одной из главных и ярких фигур в борьбе руководства со сказками, называла детскую книгу «мощным орудием коммунистического воспитания» ${ }^{42}$, призывала бороться с художественностью, «дающей неверные ориентиры» «сознательным и умелым строителям коммунистического общества ${ }^{43}$ : для юного читателя нужно реалистично изображать окружающую действительность, избегая лживых фантазий.

Поэтому именно Крупскую считают инициатором начавшейся травли не только против книг одного из самых любимых, печатаемых большими тиражами, детских писателей Корнея Ивановича Чуковского, но и против самого поэта. «Литературная газета», в которой была опубликована статья Крупской О Крокодиле, стала площадкой для острой критической дискуссии об антропоморфизме и анимизме (приемах сказочного очеловечивания предметов и животных) в детской книге, о необходимости сказки в детской литературе. Началась борьба с «чуковщиной» ${ }^{44}$, появлялись гневные рецензии в прессе не только со стороны критиков и цензоров, но и товарищей Чуковского по литературному слову. Писатель остро переживал нападки ${ }^{45}$, и для продолжения деятельности ему пришлось опубликовать письмо с «отречением» от старых сказок, о чем он впоследствии всегда жалел, а из авторов он превратился в редактора. Однако творить и создавать он не перестал, занимаясь в том числе переводами зарубежной детской литературы. К началу 1930-х годов он увлекся изучением детской психики и детским словообразованием, описав свои наблюдения в книге Om двух до пяти ${ }^{46}$.

${ }^{40}$ И.Н. Арзамасцева, Подвижники детского чтения, «Детские чтения» 2012, т. 1, № 1, сс. 26-27.

${ }^{41}$ С.Г. Маслинская, Неутомимый бореи со сказкой (Критика детской литературы в трудах Н. Крупской), «Историко-педагогический журнал» 2017, № 1, сс. 174-175.

${ }^{42}$ Н.К. Крупская, Педагогические сочинения в 10 m., Москва, Издательство АПН, 1959, т. 3, c. 439.

${ }^{43}$ Н.К. Крупская, Педагогические сочинения..., указ. соч., 1962, т. 10, с. 410.

${ }^{44} \mathrm{Mbl}$ призываем к борьбе с «Чуковщиной» (Резолюция общего собрания родителей Кремлевского детсада), «Дошкольное воспитание» 1929, № 4, с. 74.

${ }^{45}$ К.И. Чуковский, Дневник. 1901-1929, Москва, Современный писатель, 1997, сc. 430-457.

${ }^{46}$ К.И. Чуковский, Om двух до пяти, Ленинград, Издательство писателей в Ленинграде, 1933. Впервые книга вышла в свет в 1928 году под названием Маленькие дети, начиная с третьего издания книга носит название От двух до пяти. 
Незадолго до своей смерти Чуковский написал статью, в которой раскрыл свой главный секрет как автора: «Всякая искренняя детская сказка всегда бывает рождена оптимизмом. Ее живит благодатная детская вера в победу добра над злом $\rangle^{47}$.

Еще одним мэтром детской литературы тех лет был Самуил Яковлевич Маршак, который видел, как происходила перемена в жанре детской литературы, прежняя - буржуазная - система воспитания которой была обречена на слом ${ }^{48}$, и принимал самое непосредственное участие в создании новой. Вокруг Маршака в свое время объединилось много одаренных писателей, поэтов и художников. Он всегда был душой коллектива, умел находить талантливых авторов и художников в разных кругах, выискивал среди вороха рукописей «новый жанр» советской литературы, «новую книгу», «новые возможности». Маршак растил авторов для каждой темы, позволяя именитым литераторам не только выживать, но и творить. Авторы, отстраненные от взрослой литературы, нашли прибежище в детской (Даниил Иванович Хармс, Александр Иванович Введенский, Николай Алексеевич Заболоцкий). Для многих из них детская книга стала также способом писать вполголоса. «Самоограничение этих жанров успокаивает совесть писателя, не договорившего свое отношение к миру» ${ }^{49}$.

В 1934-1935 годы по стране прокатилась волна репрессий. В 1937 году, в ходе очередных доносов, было разгромлено детское издательство в Ленинграде, созданный Маршаком коллектив именовался теперь не иначе как «вредительская группа, орудовавшая в детской литературе», а авторы и редакторы стали врагами народа и были уволены или арестованы ${ }^{50}$. Многие не пережили этого события: кого-то сразу приговорили к высшей мере наказания (Николай Макарович Олейников, поэт и редактор детских журналов «Ёж» и «Чиж», был расстрелян в 1937 году; Матвей Петрович Бронштейн, автор научно-художественных статей и книг по физике для детей в журнале «Костер»- в 1938), кто-то провел годы заключений и ссылок и значительно подорвал свое здоровье (Заболоцкий, Хармс, Введенский, Белых (соавтор Республики ШКИД), Александра Иосифовна Любарская, писатель, переводчик и редактор детского отдела в ленинградском Детгизе).

${ }^{47}$ К.И. Чуковский, Признания старого сказочника, [в:] его же, Сочинения: B 2-x m, сост. и общ. ред. Е. Чуковской, т. 1, Москва, Правда, 1990. Цит. по: «Chukfamily», https://www.chukfamily.ru/kornei/prosa/articles/priznaniya-starogo-skazochnika [дата обращения: 10.11.2020].

${ }^{48}$ С.Я. Маршак, О большой литературе для маленьких, [в:] его же, Собрание сочинений в 8 m., Москва, Художественная литература, т. 6, 1971, сс. 195-243.

49 Л.Я. Гинзбург, Записные книжки. Воспоминания. Эссе, Санкт-Петербург, Искусство-СПБ, 2011, c. 79.

${ }^{50}$ А.В. Блюм, Советская цеензура..., указ. соч., с. 215. 
Самого Самуила Маршака участь его коллег не коснулась (во время разгрома он был в отпуске), однако имя его, наряду с именем Корнея Чуковского, стало крайне неприятным для общественности, ему пришлось бежать в Москву, где он продолжил творить, а также занялся переводами. Будучи прекрасным переводчиком, он отбирал созвучные его сердцу произведения, чувствовал тонкую грань между «рабским следованием за подлинником» и «преступной вольностью». Через переводы Маршак пытался передать подлинные мысли и чувства автора, его характер и душу, оставаясь при этом верным своему языку и окружающей действительности ${ }^{51}$.

Таким образом, на детскую литературу возлагалась важнейшая роль в воспитании «государственных» детей, а на авторов оказывалось давление как со стороны Партийного руководства и различных государственных инстанций, так и со стороны педагогов и коллег по цеху.

Образ советского человека, сформированный в первые десятилетия образования СССР, существующий до сих пор, вызывает многочисленные дискуссии и споры в исследовательских и научных кругах.

Так, Лев Дмитриевич Гудков, социолог и директор Аналитического центра Юрия Александровича Левады (Левада-центр), считает, что власти СССР создали «слабую личность» без собственного мнения, подпитываемую идеологическими мифами о великой державе и героическом прошлом, которое поддерживается с помощью коллективных ритуалов ${ }^{52}$. Александр Александрович Зиновьев, советский писатель и социолог, по-своему описал советского человека:

«Он всецело поддерживает свое руководство, ибо он обладает стандартным идеологизированным сознанием, чувством ответственности за страну как за целое, готовностью к жертвам и готовностью других обрекать на жертвы. Конечно, он способен и на недовольство своим положением, даже на критику порядков в стране и властей. Но в соответствующих формах и в своей мере, но не угрожающей ощутимым образом интересам общественного организма» ${ }^{53}$.

Владимир Константинович Буковский, известный русский диссидент, весьма иронично описал отношение к ребенку и детству в условиях режима:

${ }^{51}$ С.Я. Маршак, От редакиии, [в:] его же, Собрание сочинений в 8 m., Москва, Художественная литература, 1969 , т. 3, сс. 749-751.

52 Цит. по: В. Кузьменко, Старый новый человек. Как власть формировала личность советского гражданина, «Lenta.ru», 6 апреля 2016, https://lenta.ru/articles/2016/04/06/soviet_man/ [дата обращения: 23.05.2021].

${ }^{53}$ А.А. Зиновьев, Гомо советикус, Lausanne, L’Âge d'homme, 1982, с. 190. 
«Вот он, родился, этот будущий советский человек, человек нового типа. [...] Он еще, правда, не знает, как уже много он должен советскому государству и родной партии. [...] Но очень скоро с него этот долг спросят» ${ }^{54}$.

Однако в этих словах слышна и горечь: ярый борец за права человека в СССР «именно свое детство и этапы собственного воспитания [...] имел в виду, когда описывал, по каким правилам развивается в России советский человек» ${ }^{55}$, личность.

Луциан Суханек, польский профессор-филолог, исследуя тип советского человека, называет его изувеченным и развращенным, «существом-калекой», оторванным от традиций и культурных связей ${ }^{56}$. «Советский человек должен был стать реальным воплощением запрограммированных духовных ценностей и идеалов социализма» ${ }^{57}$. Однако вместо этого после революции появился «новый антропологический тип, в котором стерты характерные русские черты» ${ }^{58}$.

Активно в этом помогала пропаганда и политизированность в детской литературе. Были также книги и об устройстве жизни, поскольку дети должны были быстрее взрослеть и знать, откуда берется свет, как делают хлеб и сколько он стоит (Николай Григорьевич Смирнов Егор-монтер, Госиздат, 1928), о спорте и спортсменах (Анатолий Борисович Мариенгоф Бобка-физкультурник, Госиздат, 1930); книги о Ленине (Лев Николаевич Зилов Миллионный Ленин, Госиздат, 1926) и другие 59 . Среди авторов детской литературы можно встретить и талантливейших мастеров, для которых писать детям было призванием и сознательным выбором, и авторов, пришедших по необходимости, для выживания, судьба многих из которых была трагична. Однако победа человеческого гения

${ }^{54}$ В.К. Буковский, И возвращчается ветер. Автобиография, Москва, Захаров, 2007, сс. $55-56$.

${ }_{55}$ У. Церняк, «Вечно недовольный злопыхатель» или опасный «экстремист». Расплата Владимира Буковского с советским человеком, [в:] Другие берега русской литературы и культуры: идеи, поэтика, контексты, ред. Э. Тышковска-Каспшак, И. В. Мотеюнайте, А. И. Смирнова, Вроцлав-Краков 2021, с. 213.

${ }^{56}$ Л. Суханек, Советский человек и советский народ. Эксперимент идеологический и этнический, [в:] Współcześni Słowianie wobec własnych tradycji i mitów. Sympozjum w Castel Gandolfo 19-20 sierpnia 1996, Kraków 1997, c. 382.

${ }^{57}$ L. Suchanek, Homo sovieticus, homo russicus, homo absconditus. Wolność i zniewolenie $w$ dziełach A. Solżenicyna, A. Zinowiewa i J. Drużnikowa, [в:] Wolność w kulturze rosyjskiej: tom jubileuszowy poświęcony Pani Profesor Annie Raźny, ред. H. Kowalska-Stus, A. Krzywdzińska, Kraków, Wydawnictwo Uniwersytetu Jagiellońskiego, 2015, c. 38.

${ }^{58}$ Там же, с. 38.

59 Выставочный проект «Конструируя будущее: детская книга 1920-1930 годов» трех российских библиотек Российская государственная библиотека, Российская государственная детская библиотека, Библиотека иностранной литературы, Москва, 5 ноября - 18 декабря 2016 г. 
над всеми преградами, идеологиями и режимами оставила такой яркий след в культуре и истории, в котором настоящее искусство, в частности, великолепные литературные произведения для детей и прекрасные переводы зарубежных книг заносятся в золотой фонд детской литературы и остаются в вечности, становясь внеисторическими шедеврами мирового искусства.

\section{Литература}

Арзамасцева И.Н., Подвижники детского чтения, «Детские чтения» 2012, №1, том 1, сс. 12-42.

Блюм А.В., Советская цุензура в эпоху тотального террора 1929-1953, СанктПетербург, Академический проект, 2000, 312 сc.

Буковский В.К., И возвращуается ветер. Автобиография, Москва, Захаров, 2007, 416 c.

Бухарин Н.И., Борьба за новых людей, [в:] его же, Борьба за кадры, Москва, Ленинград, Молодая гвардия, 1926, сс. 25-36.

Геллер М.Я., Машина и винтики. История формирования советского человека, Лондон, Overseas Publications Interchange Ltd, 1985, 336 cс.

Гинзбург Л.Я., Записные книжки. Воспоминания. Эссе, Санкт-Петербург, Искусство-СПБ, 2011, 766 с.

Горький М., О старом и новом человеке, [в:] его же, Публицистические статьи, Ленинград, ОГИЗ, 1933, сс. 353-362.

Декрет от 6 июня 1922 года. Положение о Главном управлении по делам литературы и издательств (Главлит), «Открытый текст. Электронное периодическое издание», http://opentextnn.ru/old/censorship/russia/sov/law/ snk/1922/index.html@id=3382 [дата обращения: 10.01.2021].

Декрет СНК об учреждении Государственного ученого совета. 4 марта, [в:] Декреть Советской власти. Т. IV. 10 ноября 1918 г. - 31 марта 1919 г., Москва, 1968, сс. 639-640.

Декрет Совета Народных Комиссаров. Об организации дела народного образования в Российской Республике (Положение.), [в:] Собрание узаконений и распоряжений правительства за 1917-1918 г2., № 46 от 27 (14) июня 1918 г., Отдел первый, ст. 551, Управление делами Совнаркома СССР, Москва, 1942, сс. 621-625.

Демидова Т.В., Образ идеального советского человека в печати СССР 1930-х годов, «Исторические, философские, политические и юридические науки, культурология и искусствоведение. Вопросы теории и практики» 2012, № 4 (18): в 2-х ч, ч. I, сс. 50-52. 
Доклад А.М. Горького о советской литературе, [в:] Первый Всесоюзный съезд советских писателей 1934. Стенографический отчет, Москва, Государственное издательство Художественная литература, 1934, сс. 5-18.

Дружников Ю.И., Доносчик 001, или Вознесение Павлика Морозова, Москва, Augsburg, Im Werden Verlag, 2003, 94 cc.

Залкинд А.Б., Педология в СССР, Москва, Работник просвещения, 1929, 82 сc. Зиновьев А.А., Гомо советикус, Lausanne, L'Âge d'homme, 1982, 199 cc.

Кормчий Л., Забытое оружие. О детской книге, «Правда» 1918, № 28, 17 февраля, с. 3.

Крупская Н.К., Педагогические сочинения в 10 m., Москва, Издательство АПН, т. 3, 1959, 798 c.

Крупская Н.К., Педагогические сочинения в 10 m., Москва, Издательство АПН, т. $10,1962,808 \mathrm{c}$.

Кузнецов А., Детская литература, «Универсальная научно-популярная онлайн-энциклопедия „Кругосвет“», https://www.krugosvet.ru/enc/kultura i_obrazovanie/literatura/DETSKAYA_LITERATURA.html [дата обращения: 07.04.2020].

Кузьменко В., Старый новый человек. Как власть формировала личность советского гражданина, «Lenta.ru», 6 апреля 2016, https://lenta.ru/articles/2016/04/06/soviet_man/ [дата обращения: 23.05.2021].

Ленин В.И., Задачи союзов молодежи. Речь на III Всероссийском съезде Российского Коммунистического Союза Молодежи 2 октября 1920 года, [в:] его же, Полное собрание сочинений в 55 томах, Москва, Издательство политической литературы, 1958, том 41, сс. 298-318.

Маршак С.Я., Собрание сочинений в 8 m., Москва, Художественная литература, 1969, т. 3, $831 \mathrm{cc.}$

Маршак С.Я., Собрание сочинений в 8 m., Москва, Художественная литература, 1971 , т. 6, $671 \mathrm{cc}$.

Маслинская С.Г., Неутомимый бореи со сказкой (Критика детскойлитературы в трудах Н. Крупской), «Историко-педагогический журнал» 2017, № 1, cс. 172-186.

Маяковский В., Большое собрание стихотворений и поэм в одном томе, Москва, Эксмо, 1312 сс.

Мы призываемк борьбе с «Чуковщиной» (Резолюиия общего собрания родителей Кремлевского детсада), «Дошкольное воспитание» 1929, № 4, с. 74.

Октябрьская О.С., Пути развития русской детской литературы ХХ века (19202000-е гz.), Москва, МАКС Пресс, 2012, 359 сс.

Приложение к протоколу заседания № 68 (n. 9) Коллегии Народного комиссариата по просвещению РСФСР. Положение об Институте по 
детскому чтению, принятое на заседании Коллегии Наркомпроса РСФСР 15 июля 1920 г., [в:] Архив новейшей истории России. Протоколь и постановления Наркомпроса РСФСР. В 3 кн. Кн. 3. Январь - декабрь 1920 г., Москва, 2016, сс. 428-429.

Соколов Ю., Детская литература, [в:] Литературная энщиклопедия: Словарь литературных терминов: в 2-х т., Москва, Ленинград, под ред. Н. Бродского, А. Лаврецкого, Э. Лунина, В. Львова-Рогачевского, М. Розанова, В. Чешихина-Ветринского, 1925, т. 1, сс. 194-199.

Суханек Л., Советскийчеловек и советскийнарод. Экспериментидеологический u этнический, [в:] Wspótcześni Stowianie wobec własnych tradycji i mitów. Sympozjum w Castel Gandolfo 19-20 sierpnia 1996, Kraków, 1997, cc. 379382.

Тумова Н., На ниве просвещения, «Учительская газета», № 09, 26 февраля 2019, [в:] https://ug.ru/na-nive-prosveshheniya/ [дата обращения: 25.05.2021].

Фомин Д.В., Вступление, [в:] В. В. Маяковский, Что такое хорошо и что такое плохо, репринтное издание, Москва, Арт-Волхонка, 2018, обложка.

Церняк У., «Вечно недовольный злопыхатель» или опасный «экстремист». Расплата Владимира Буковского с советским человеком, [в:] Другие берега русской литературы и культуры: идеи, поэтика, контексты, ред. Э. Тышковска-Каспшак, И.В. Мотеюнайте, А.И. Смирнова, Вроцлав-Краков, Wydawnictwo «Scriptum», 2021, cc. 211-222.

Чуковский К.И., Дневник. 1901-1929, Москва, Современный писатель, 1997, $541 \mathrm{cc}$.

Чуковский К.И., Признания старого сказочника, [в:] его же, Сочинения: B 2-x m, сост. и общ. ред. Е. Чуковской, т. 1, Москва, Правда, 1990. Цит. по: «Chukfamily», [в:] https://www.chukfamily.ru/kornei/prosa/articles/priznaniya-starogo-skazochnika [дата обращения: 10.11.2020].

Brzóstowicz-Klajn M., Pawlika Morozowa wzorzec, [в:] Słownik realizmu socjalistycznеgo, ред. Z. Łapiński, W. Tomasik, Kraków, Universitas, 2004, c. 184.

Suchanek L., Homo sovieticus, homo russicus, homo absconditus. Wolność i zniewolenie w dziełach A. Solżenicyna, A. Zinowiewa i J. Drużnikowa, [в:] Wolność w kulturze rosyjskiej: tom jubileuszowy poświęcony Pani Profesor Annie Raźny, ред. Hanna Kowalskia-Stus i Agata Krzywdzińska, Kraków, Wydawnictwo Uniwersytetu Jagiellońskiego, 2015, cc. 37-50.

Suchanek L., Kultura masowa $w$ Rosji i radziecki eksperyment antropologiczny, «Kultura Słowian. Rocznik Komisji Kultury Słowian PAU» 2016, т. XII, cc. 727. 


\section{References}

Arzamastseva I.N., Podvizhniki detskogo chteniia [Promoters of Children's Reading], "Children's Reading" 2012, no. 1, vol. 1, pp. 12-42.

Blium A.V., Sovetskaia tsenzura v epokhu total'nogo terrora 1929-1953 [Soviet Censorship in the Era of Total Terror], St. Petersburg, Akademicheskii Proekt Publ., 2000, 312 pp.

Brzóstowicz-Klajn M., Pawlika Morozowa wzorzec [Pavlik Morozov's model], [in:] Łapiński Z., Tomasik W. (Eds.), Słownik realizmu socjalistycznego [Dictionary of Socialist Realism], Kraków, Universitas, 2004, p. 184.

Bukharin N.I., Bor'ba za novykh liudei [Struggle for the New People], [in:] Bukharin N.I., Bor'ba za kadry [Struggle for Personnel], Moscow, Leningrad, Molodaia Gvardiia Publ., 1926, pp. 25-36.

Bukovsky V., I vozvrashchaetsia veter. Avtobiografiia [To Build a Castle: My Life as a Dissenter], Moscow, Zakharov Publ., 2007, 416 pp.

Chukovsky K.I., Dnevnik. 1901-1929 [Diary. 1901-1929], Moscow, Sovremennyj pisatel' Publ., 1997, 541 pp.

Chukovsky K.I., Priznaniia starogo skazochnika [Confessions of an Old Storyteller], "Chukfamily". Available at: https://www.chukfamily.ru/kornei/prosa/articles/ priznaniya-starogo-skazochnika [accessed: 10.11.2020].

Cierniak U., "Vechno nedovol'nyi zlopykhatel"” ili opasnyi "ekstremist". Rasplata Vladimira Bukovskogo s sovetskim chelovekom ["A Constantly Dissatisfied Grump" or “a Dangerous Extremist". Vladimir Bukovsky's Notion of a Soviet Man], [in:] E. Tyszkowska-Kasprzak, I. Motejunajte, A. Smirnowa (Eds.), Drugie berega russkoj literatury i kul'tury: idei, poetika, konteksty [Other Shores of Russian Literature and Culture: Ideas, Poetics, and Contexts] Wrocław, Kraków, Wydawnictwo "Scriptum", 2021, pp. 211-222.

Dekret ot 6 iiunia 1922 goda. Polozhenie o Glavnom upravlenii po delam literatury $i$ izdatel'stv (Glavlit) [Decree of June 6, 1922. Regulations on the Main Administration for Literary and Publishing Affairs (Glavlit)], "Otkrytyi tekst. Elektronnoe periodicheskoe izdanie" [Open Text. Electronic periodical]. Available at: http://opentextnn.ru/old/censorship/russia/sov/law/snk/1922/index.html@id=3382 [accessed: 10.01.2021].

Dekret SNK ob uchrezhdenii Gosudarstvennogo uchenogo soveta. 4 marta [Decree of the Council of People's Commissars on the Establishment of the State Academic Council. March 4] [in:] Dekrety Sovetskoi vlasti. Vol. IV. 10.11.1918. - 31.03.1919 [Decrees of the Soviet Government. Vol. IV. 10.11.1918 31.03.1919], Moscow, 1968, pp. 639-640. 
Dekret Soveta Narodnyh Komissarov. Ob organizacii dela narodnogo obrazovanija $v$ Rossijskoj Respublike (Polozhenie) [Decree of the Council of People's Commissars. On the Organization of Public Education in the Russian Republic (Regulation) ], [in:] Sobranie uzakonenij i rasporjazhenij pravitel'stva za 19171918 gg., № 46 ot 27 (14) ijunja 1918, Otdel pervyj, st. 551, Upravlenie delami Sovnarkoma SSSR [Collection of Legalizations and Orders of the Government for 1917-1918, no 46 from 27 (14) June 1918, Trial Division, art. 551, Administration of the USSR Council of People's Commissars], Moscow, 1942, pp. 621-625.

Demidova T.V., Obraz ideal'nogo sovetskogo cheloveka v pechati SSSR 1930-kh godov [The Image of the Ideal Soviet Man in the Press of the USSR in the 1930s], "Historical, Philosophical, Political and Law Sciences, Culturology and Study of Art. Issues of Theory and Practice" 2012, no. 4 (18): in 2 vols., p. I, pp. 50-52.

Doklad A.M. Gor'kogo o sovetskoj literature [A.M. Gorky about the Soviet Literature] [in:] Pervyj Vsesojuznyj s'ezd sovetskih pisatelej 1934. Stenograficheskij otchet [First All-Union Congress of Soviet Writers 1934. Verbatim Report], Moscow, Gosudarstvennoe izdatel'stvo Hudozhestvennaja literatura Publ., 1934, pp. 5-18. Druzhnikov Ju., Donoschik 001, ili Voznesenie Pavlika Morozova [Informer 001, or the Myth of Pavlik Morozov], Moscow-Augsburg, Im Werden Verlag, 2003, 94 p.

Fomin D.V., Vstuplenie [Introduction] [in:] Mayakovsky V., Chto takoe khorosho i chto takoe plokho [What Is Good and What Is Bad], reprint edition, Moscow, ArtVolkhonka Publ., 2018, cover.

Ginzburg L.Ia., Zapisnye knizhki. Vospominaniia. Esse [Notebooks. Memories. Essay], St. Peterburg, Iskusstvo-SPB Publ., 2011, 766 pp.

Gorky M., O starom i novom cheloveke [About the Old and the New Man], [in:] Gorky M., Publitsisticheskie stat'i [Journalistic Articles], Leningrad, OGIZ Publ., 1933, pp. 353-362.

Heller M., Mashina i vintiki. Istoriia formirovaniia sovetskogo cheloveka [Cogs in the Wheel: The Formation of Soviet Man], London, Overseas Publications Interchange Ltd, 1985, $336 \mathrm{pp}$.

Kormchij L., Zabytoe oruzhie. O detskoi knige [Forgotten Weapon. About Children's Book], "Pravda" 1918, 17 February, no. 28, p. 3.

Krupskaya N.K., Pedagogicheskie sochineniia v 10 t. [Pedagogical Works in 10 Volumes], Moscow, APN Publ., vol. 3, 1959, 798 pp.

Krupskaya N.K., Pedagogicheskie sochineniia v 10 t. [Pedagogical Works in 10 Volumes], Moscow, APN Publ., vol. 10, 1962, 808 pp.

Kuz'menko V., Staryi novyi chelovek. Kak vlast' formirovala lichnost' sovetskogo grazhdanina [An Old New Man. How the Government Shaped the Personality 
of a Soviet Citizen], "Lenta.ru”. Available at: https://lenta.ru/articles/2016/04/06/ soviet_man/ [accessed: 23.05.2021].

Kuznecov A., Detskaia literatura [Children's Literature], "Universal'naia nauchnopopuliarnaia onlain-entsiklopediia "Krugosvet"”. Available at: https://www. krugosvet.ru/enc/kultura_i_obrazovanie/literatura/DETSKAYA_ LITERATURA.html [accessed: 07.04.2020].

Lenin V.I., Zadachi soiuzov molodezhi. Rech'na III Vserossiiskom s"ezde Rossiiskogo Kommunisticheskogo Soiuza Molodezhi 2 oktiabria 1920 goda [The Tasks of Youth Unions. Speech at the III All-Russian Congress of the Russian Communist Youth Union on October 2, 1920], [in:] Lenin V.I., Polnoe sobranie sochinenij v 55 tomah [Complete Works in 55 volumes], Moscow, Izdatel'stvo politicheskoj literatury Publ., 1958, vol. 41, pp. 298-318.

Mayakovsky V.V., Bol'shoe sobranie stikhotvorenii i poem $v$ odnom tome [The Greate Collection of Poems in One Volume], Moscow, Eksmo, 1312 pp.

Marshak S.Ja., Sobranie sochinenii v 8 t. [Complete Works in 8 volumes], Moscow, Hudozhestvennaja literatura Publ., 1969, vol. 3, 831 pp.

Marshak S.Ja., Sobranie sochinenii v 8 t. [Complete Works in 8 volumes], Moscow, Hudozhestvennaja literatura Publ., 1971, vol. 6, 671 pp.

Maslinskaia S.G., Neutomimyi borets so skazkoi (Kritika detskoi literatury v trudakh N. Krupskoi) [Tireless Fighter with a Fairy Tale (Criticism of Children's Literature in the Works of N. Krupskaya)], "History of Education Journal" 2017, no. 1, pp. 172-186.

My prizyvaem k bor'be s "Chukovshchinoi" (Rezoliutsiia obshchego sobraniia roditelei Kremlevskogo detsada) [We Call for Fight Against "Chukovshchina" (Resolution of the General Parents Meeting of the Kremlin Kindergarten)], "Preschool education" 1929, no. 4, p. 74.

Oktiabr'skaia O.S., Puti razvitiia russkoi detskoi literatury XX veka (1920-2000-e gg.) [Paths of Development of the Russian Children's Literature], Moscow, MAKS Press Publ., 2012, 359 pp.

Prilozhenie k protokolu zasedaniia № 68 (p. 9) Kollegii Narodnogo komissariata po prosveshcheniiu RSFSR. Polozhenie ob Institute po detskomu chteniiu, priniatoe na zasedanii Kollegii Narkomprosa RSFSR 15 iiulia $1920 \mathrm{~g}$. [Appendix to the Summary Record of the Meeting No. 68 (item 9) of the Collegium of the People's Commissariat for Education of the RSFSR. Regulations on the Institute for Children's Reading, Adopted at the Meeting of the Collegium of the RSFSR People's Commissariat for Education on July 15, 1920], [in:] Arkhiv noveishei istorii Rossii. Protokoly i postanovleniia Narkomprosa RSFSR. V 3 kn. Kn. 3. Ianvar' - dekabr' 1920 g. [Archive of the Contemporary History of Russia. 
Protocols and Resolutions of the RSFSR People's Commissariat for Education. In 3 Books. Book 3. January - December 1920], Moscow, 2016, pp. 428-429. Sokolov Iu., Detskaia literatura [Children's Literature], [in:] Literaturnaia entsiklopediia: Slovar' literaturnykh terminov: $v$ 2-kh $t$. [Literary encyclopedia. Literary Terms Dictionary in 2 Volumes], N. Brodskii, A. Lavretskii, E. Lunin, V. L’vov-Rogachevskii, M. Rozanov, V. Cheshikhin-Vetrinskii (Eds.), Moscow, Leningrad, 1925, vol.1, pp. 194-199.

Suchanek L., Homo sovieticus, homo russicus, homo absconditus. Wolność i zniewolenie w dziełach A. Solżenicyna, A. Zinowiewa i J. Drużnikowa [Homo Sovieticus, Homo Russicus, Homo Absconditus. Freedom and Enslavement in the Works of A. Solzhenitsyn, A. Zinoviev and J. Druznikov], [in:] Wolność w kulturze rosyjskiej: tom jubileuszowy poświęcony Pani Profesor Annie Raźny [Freedom in Russian Culture: a Jubilee Volume Devoted to Professor Anna Raźny], H. Kowalska-Stus and K. Krzywdzińska (Eds.), Kraków, Wydawnictwo Uniwersytetu Jagiellońskiego, 2015, pp. 37-50.

Suchanek L., Kultura masowa $w$ Rosji i radziecki eksperyment antropologiczny, [Mass Culture in Russia and Soviet Anthropological Experiment], "Kultura Słowian. Rocznik Komisji Kultury Słowian PAU” 2016, vol. XII, pp. 7-27.

Suhanek L., Sovetskij chelovek i sovetskij narod. Jeksperiment ideologicheskij i jetnicheskij [Soviet Man and Soviet People. Ideological and Ethnic Experiment], [in:] Wspótcześni Stowianie wobec własnych tradycji i mitów. Sympozjum w Castel Gandolfo 19-20 sierpnia 1996 [Contemporary Slavs in the Face of Their Own Traditions and Myths. Symposium in Castel Gandolfo, August 19-20, 1996], Kraków 1997, pp. 379-382.

Tumova N., Na nive prosveshcheniia [In the Field Education], "Uchitel'skaja gazeta", no. 09, 26 February 2019, Available at: https://ug.ru/na-nive-prosveshheniya/ [accessed: 25.05.2021].

Zalkind A.B., Pedologiia v SSSR [Pedology in the USSR], Moscow, Rabotnik prosveshhenija Publ., 1929, 82 pp.

Zinoviev A.A., Gomo sovetikus [Homo Sovieticus], Lausanne, L'Âge d'homme, 1982, 199 pp. 
